\title{
The Role of Serum in Acanthocyte Autohemolysis and Membrane Lipid Composition*
}

\author{
Peter Ways † and Ernest R. Simon $\frac{\dot{t}}{6}$ \\ (From the Department of Medicine, University of Washington School of Medicine, and the \\ King County Central Blood Bank, Seattle, Wash.)
}

Experiments reported in the accompanying paper (1) showed that an abnormally high percentage of red cells from patients with acanthocytosis hemolyze when incubated at $37^{\circ}$ or $4^{\circ} \mathrm{C}$ for 48 hours. This abnormal lysis was inhibited by heparin, supplementary glucose, and additions of normal serum.

This report partially identifies the components of normal serum that inhibit such autohemolysis and the lipid composition and autohemolytic behavior of "older" and younger cells separated by centrifugation. The implications and interrelationships of these data are discussed.

\section{Materials and Methods}

Methodology for the extraction and analysis of lipids has been described (2). Paper chromatography of phospholipids, however, was modified: a) During preparation of the silicic acid paper, an extra (fifth) rinse in 0.12 or $0.25 \%$ disodium EDTA was included, and $b$ ) the chromatograms were developed in diisobutyl ketone, $n$-butyl ether, acetic acid, and water $(20 / 20 / 25 / 2$, vol/ vol) for 14 to 20 hours. Distinct separation of ethanolamine phosphoglycerides, serine phosphoglycerides, lecithin, sphingomyelin, and lysolecithin was achieved. Phosphatidyl inositol migrated with or slightly behind sphingomyelin.

Lipoproteins of density less than $1.063,1.063$ to 1.110 , 1.110 to 1.21 , and the ultracentrifugal residue (density > 1.21), were isolated from normal nonlactescent fasting serum by the method of Havel, Eder, and Bragdon (3). Each fraction was dialyzed for 12 to 18 hours against $0.9 \% \mathrm{NaCl}$ before adding it to incubation mixtures.

Lipid emulsions were prepared by dissolving normal plasma lipid extracts in 1 vol chloroform/methanol

* Submitted for publication October 25, 1963 ; accepted February 17, 1964.

These studies were assisted by U. S. Public Health Service grants A-5984 and H-7326 and by grants from the American Heart Association, supported by the Washington State Heart Association.

$\dagger$ Established Investigator, American Heart Association.

$¥$ Present address : Department of Medicine, University of New Mexico, Albuquerque, N. Mex.
$(\mathrm{C} / \mathrm{M}) \quad 2 / 1$ and removing nonlipid impurities with 0.27 vol of $0.1 \mathrm{M}$ KCL. After recovery from the organic phase, the total lipid was either brought to convenient volume in benzene or separated immediately on a silicic acid column into two fractions: neutral lipid (free cholesterol, cholesterol esters, triglyceride) and phospholipids. Appropriate portions of lipid were pipetted into a glass manual homogenizer, and the solvent was evaporated in a stream of nitrogen. After addition of 2 to $10 \mathrm{ml}$ of either the patient's plasma, potassium phosphate buffer (310 mOsm, $\mathrm{pH} 7.4)$ or $0.9 \% \mathrm{NaCl}$, the lipid mixture was emulsified in the homogenizer. In a few experiments, the resultant opaque suspensions were used without further modification. However, most of the suspensions were exposed to $10-\mathrm{kc}$ ultrasonic vibrations for 6 to $45 \mathrm{~min}$ utes at 4 to $20^{\circ} \mathrm{C}$. Considerable clearing usually occurred, although none of the suspensions attained the transparency of the original suspending medium.

The trichloroacetic acid (TCA) filtrate of normal serum was prepared by adding 1 vol of serum to 1 vol of ice-cold $10 \%$ TCA. The mixture was stirred and centrifuged in the cold. The supernatant solution was decanted, then extracted with equal volumes of cold ethyl ether until neutral, and aerated for 5 minutes to remove the remaining ether. The final extract represented a 2-fold dilution of the original serum. The perchloric acid (PCA) filtrate of normal serum was prepared by adding 1 vol cold $0.6 \mathrm{~N} \mathrm{PCA}$ to 1 vol serum, stirring and centrifuging the mixture, and neutralizing the supernatant solution with $\mathrm{KOH}$. The final extract represented a 2.2-fold dilution of the original serum.

Centrifugal separation of acanthocytes into different age groups was described in the accompanying communication (1). The determinations on the cell populations designated "average" were made either on whole blood or on the center fraction of the centrifuged cell column. In a given blood sample these two groups were comparable both morphologically and in their reticulocyte content.

Autohemolysis, expressed as the percentage of cells that lysed after 44 to 49 hours incubation at $37^{\circ}$ or $4^{\circ} \mathrm{C}$, was determined on 2-ml samples of whole defibrinated blood (1), supplemented with the test fractions as indicated. Blood was obtained from the two patients described in the accompanying paper (1). Patient 1 received dietary supplements of safflower oil (10 to $30 \mathrm{ml}$ daily) for a 5-week period during these studies without 
measurable effect on autohemolysis. Except where stated, blood from Patient 1 was used. In all experiments normal blood with the same additions as the patient's blood was studied concurrently.

\section{Results}

A) The effect of serum, serum lipoproteins, and lipid emulsions on the abnormal autohemolysis

1) Normal serum. The addition of serum from four normal individuals with serum cholesterol values of 200 to $260 \mathrm{mg}$ per $100 \mathrm{ml}$ prevented the abnormal lysis of the patient's defibrinated blood at $37^{\circ} \mathrm{C}$. The results of three experiments in which the effect was titrated are presented in Figure 1. In each instance if as little as $4 \%$ of the total serum present in the incubation mixture was normal, the accelerated lysis was reduced; about $7 \%$ was required to prevent the abnormal lysis completely. Sera from the patient's parents and brother were as active as normal sera, but additional increments of the patient's own serum (up to $20 \%$ ) did not reduce the lysis. Washing the patient's cells three times in sterile saline before incubation with normal serum at $37^{\circ}$ did not prevent inhibition of the abnormal lysis, and normal cells washed similarly did not show excessive

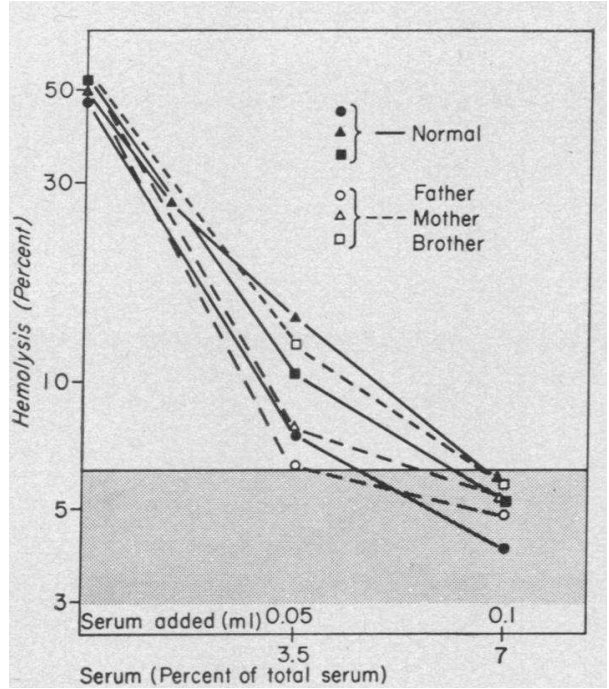

Fig. 1. The INHIBITORY EFFeCt OF SERA ON ACANTHOCYTE AUtohemolysis (semilog plot). In all of these experiments, defibrinated blood was incubated 48 hours at $37^{\circ} \mathrm{C}$. The shaded area represents the range of hemolysis for normal blood incubated in an identical manner.

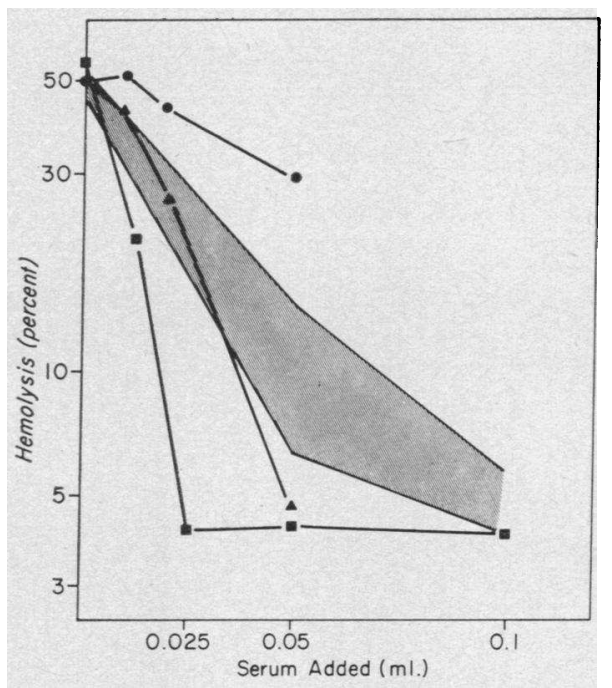

Fig. 2. THE EFFECT OF HYPERLIPIDEMIC SERA ON ACANTHOCYTE AUTOHEMOLYSIS (semilog plot). In all of these experiments, defibrinated blood was incubated 48 hours at $37^{\circ} \mathrm{C}$. The shaded area represents the inhibitory range of normal sera (see Figure 1). - Hyperlipidemic patient with an elevation primarily of serum triglycerides; $\square$, patient with hypercholesterolemia and hyperphospholipidemia; $\boldsymbol{\Delta}-\boldsymbol{\Delta}$, patient with only slightly elevated cholesterol (see text).

lysis when incubated with the patient's serum. In a single experiment, $7 \%$ normal serum also prevented the abnormal lysis of the blood from $\mathrm{Pa}$ tient 2 .

Normal serum retained its effectiveness in the $37^{\circ}$ system after heating at $56^{\circ} \mathrm{C}$ for 30 minutes or dialysis against $0.9 \% \mathrm{NaCl}$ for 24 hours. Neutralized serum filtrates, prepared by TCA or PCA precipitation, did not inhibit the lysis.

At $4^{\circ}$ normal serumi also inhibited the abnormal lysis but not as efficiently as at $37^{\circ}$. In the single experiment in which the effect was titrated, lysis was reduced from $35.4 \%$ to 3.3 and $1.7 \%$ by 10 and $20 \%$ normal serum, respectively, whereas lysis in the normal control was $0.4 \%$. In another experiment at $4^{\circ}, 50 \%$ normal serum reduced autohemolysis from 27.5 to $0.9 \%$ (control, $0.2 \%)$.

2) Serum lipoproteins. Low density plasma lipoproteins are absent (4-6), and high density lipoprotein is deficient in acanthocytosis $(2,4,7)$. Therefore, ultracentrifugally prepared serum lipoproteins (and some of their constituents) were tested for their antihemolytic potency. As 
TABLE I

The effect of serum lipoprotein fractions on acanthocyte autohemolysis

\begin{tabular}{|c|c|c|c|c|c|c|c|c|c|}
\hline \multirow[b]{2}{*}{$\begin{array}{l}\text { Exper- } \\
\text { iment }\end{array}$} & \multirow[b]{2}{*}{ Lipoprotein } & \multirow[b]{2}{*}{$\begin{array}{c}\text { Amount } \\
\text { added }\end{array}$} & \multirow{2}{*}{$\begin{array}{c}\text { Normal } \\
\text { serum } \\
\text { equivalent* }\end{array}$} & \multicolumn{2}{|c|}{ Lipid added $\dagger$} & \multicolumn{2}{|c|}{$\begin{array}{l}\text { Final total } \\
\text { concentration } \\
\text { of lipid } \ddagger\end{array}$} & \multicolumn{2}{|c|}{ Hemolysis $37^{\circ} \mathrm{C}$} \\
\hline & & & & LP & Chol & $\overline{L P}$ & $\frac{\mathrm{Ch}}{\mathrm{Chol}}$ & $\begin{array}{l}\text { Without } \\
\text { addition }\end{array}$ & $\begin{array}{c}\text { With } \\
\text { addition }\end{array}$ \\
\hline \multirow{3}{*}{ A } & & \multicolumn{2}{|r|}{$m l$} & \multicolumn{2}{|c|}{$\mu g$} & \multicolumn{2}{|c|}{$\mu g / m l$ serum } & \multicolumn{2}{|c|}{$\%$} \\
\hline & Less than 1.063 & $\begin{array}{l}0.10 \\
0.05\end{array}$ & $\begin{array}{l}0.20 \\
0.10\end{array}$ & $\begin{array}{l}8 \\
4\end{array}$ & $\begin{array}{l}340 \\
170\end{array}$ & $\begin{array}{l}23 \\
22\end{array}$ & $\begin{array}{l}567 \\
454\end{array}$ & 61 & $\begin{array}{l}3.7 \\
14\end{array}$ \\
\hline & Greater than 1.063 & 0.37 & 0.31 & 16 & 210 & 25 & 397 & & 4.8 \\
\hline \multirow[t]{3}{*}{ B } & Less than 1.063 & 0.05 & 0.15 & 4 & 165 & 22 & 460 & 16 & 2.4 \\
\hline & $1.063-1.110$ & $\begin{array}{l}0.30 \\
0.10\end{array}$ & $\begin{array}{l}0.15 \\
0.05\end{array}$ & $\begin{array}{l}3 \\
1\end{array}$ & $\begin{array}{l}66 \\
22\end{array}$ & $\begin{array}{l}22 \\
19\end{array}$ & $\begin{array}{l}324 \\
338\end{array}$ & 30 & 17.9 \\
\hline & Greater than 1.110 & $\begin{array}{l}0.30 \\
0.10\end{array}$ & $\begin{array}{l}0.33 \\
0.11\end{array}$ & $\begin{array}{l}6 \\
2\end{array}$ & $\begin{array}{l}75 \\
25\end{array}$ & $\begin{array}{l}19 \\
20\end{array}$ & $\begin{array}{l}331 \\
343\end{array}$ & & 13 \\
\hline \multirow[t]{3}{*}{$\mathrm{C}$} & $1.063-1.110$ & $\begin{array}{l}0.20 \\
0.075\end{array}$ & $\begin{array}{l}0.45 \\
0.17\end{array}$ & $\begin{array}{r}13 \\
5\end{array}$ & $\begin{array}{r}187 \\
70\end{array}$ & $\begin{array}{l}25 \\
23\end{array}$ & $\begin{array}{l}428 \\
382\end{array}$ & 40 & 23 \\
\hline & $1.110-1.21$ & $\begin{array}{l}0.30 \\
0.10\end{array}$ & $\begin{array}{l}0.90 \\
0.30\end{array}$ & $\begin{array}{r}22 \\
7\end{array}$ & $\begin{array}{r}153 \\
51\end{array}$ & $\begin{array}{l}36 \\
24\end{array}$ & $\begin{array}{l}378 \\
362\end{array}$ & & $\begin{array}{l}6.1 \\
26\end{array}$ \\
\hline & Greater than 1.21 & 0.5 & 0.60 & 3 & 55 & 16 & 283 & & 78 \\
\hline
\end{tabular}

* Normal serum equivalent $=$ the calculated amount of whole serum from which the added lipoprotein was derived. $\dagger$ LP, lipid phosphorus; Chol, cholesterol.

$\ddagger$ These figures are based on the following values for the patient's blood: hematocrit, $35 \%$; lipid phosphorus, $20 \mu \mathrm{g}$ per $\mathrm{ml}$ serum; cholesterol, $350 \mu \mathrm{g}$ per $\mathrm{ml}$ serum.

indicated in Table $\mathrm{I}$, both low (density $<1.063$ ) and high (density $>1.063$ or 1.063 to 1.21 ) density lipoprotein inhibited the abnormal lysis. The ultracentrifugal residue (density $>1.21$ ) increased the lysis. As at $37^{\circ}$, low density lipoproteins also reduced autohemolysis at $4^{\circ}$, but other fractions were not tested. A commercial " $\beta$-lipoprotein" preparation ${ }^{1}$ was without effect and on analysis contained virtually no lipid phosphorus or cholesterol. Added glucosamine (60 and 120 $\mu \mathrm{g})$ and $N$-acetylneuraminic acid (75 and $150 \mu \mathrm{g}$ ), both components of normal lipoproteins (8), had no effect on the lysis.

3) Effect of serum from patients with hyperlipidemia. Figure 2 indicates that the in vitro antihemolytic effect of serum from one hyperlipidemic patient with elevated levels of lipid phosphorus and cholesterol (18 and $550 \mathrm{mg}$ per 100 ml, respectively) was two to three times as active as normal serum. Another serum having elevated triglycerides but normal plasma phospholipid and cholesterol (10 and $202 \mathrm{mg}$ per $100 \mathrm{ml}$, respectively) was equal to or less active than normal serum. The activity of serum from a third in-

\footnotetext{
1 Human plasma Fraction III-O, no. H.P. 66-88, Hyland Laboratories, Los Angeles, Calif.
}

dividual with slightly elevated cholesterol (300 $\mathrm{mg}$ per $100 \mathrm{ml}$ ) and normal lipid phosphorus (9.7 $\mathrm{mg}$ per $100 \mathrm{ml}$ ) is also shown.

4) The effect of lipid emulsions. Using total plasma lipid, neutral lipid (free cholesterol, cholesterol esters, triglycerides), phospholipid, phospholipid and neutral lipid (separated by silicic acid chromatography and then recombined), or phospholipid and cholesterol (U.S.P.) combined, we prepared emulsions either in the patient's serum, in $0.9 \% \mathrm{NaCl}$, or in potassium phosphate buffer. Some emulsions were opaque, others opalescent, and a few clear. Two preparations (1a, phospholipid plus neutral lipid; 2a, total plasma lipid) provided significant protection (Table II). In experiment $1 \mathrm{~b}$ (plasma phospholipid plus commercial cholesterol), some protection was observed, but paradoxically, the results were better with the smaller additions. Although phospholipid alone resulted in the clearest emulsions, these did not diminish the autohemolysis (e.g., experiment 3). Satisfactory emulsions of cholesterol or neutral lipid alone were not obtained. ${ }^{2}$ Supple-

2 When these "emulsions" were centrifuged 30 minutes at $1,500 \mathrm{~g}$, the added cholesterol and neutral lipid floated to the top of the tube. 
TABLE II

Effect of lipid emulsions on acanthocyle autohemolysis

\begin{tabular}{|c|c|c|c|c|c|c|c|}
\hline \multirow[b]{2}{*}{ Experiment } & \multicolumn{3}{|c|}{ Emulsion* } & \multicolumn{2}{|c|}{ Lipid added } & \multicolumn{2}{|c|}{ Autohemolysis } \\
\hline & Lipid & Medium & Appearance & $\begin{array}{c}\text { Phos- } \\
\text { phorus }\end{array}$ & $\begin{array}{l}\text { Choles- } \\
\text { terol }\end{array}$ & $\begin{array}{l}\text { Without } \\
\text { lipid }\end{array}$ & $\begin{array}{l}\text { With } \\
\text { lipid }\end{array}$ \\
\hline & & & & \multicolumn{2}{|c|}{ total $\mu \mathrm{g}$} & \multicolumn{2}{|c|}{$\%$} \\
\hline $1 \mathrm{a}$ & $\mathrm{PL}+\mathrm{NL}$ & $0.9 \% \mathrm{NaCl}$ & Opalescent & $\begin{array}{r}8 \\
24 \\
48\end{array}$ & $\begin{array}{l}160 \\
480 \\
960\end{array}$ & 40 & $\begin{array}{l}29 \\
18 \\
13\end{array}$ \\
\hline b & $\mathrm{PL}+\mathrm{Chol}$ & $0.9 \% \mathrm{NaCl}$ & Opaque & $\begin{array}{r}8 \\
24 \\
48\end{array}$ & $\begin{array}{l}160 \\
480 \\
960\end{array}$ & 40 & $\begin{array}{l}18 \\
43 \\
28\end{array}$ \\
\hline $2 a$ & $\mathrm{TL}$ & $\begin{array}{c}\text { Patient's } \\
\text { serum }\end{array}$ & Clear & 8 & 200 & 49 & 15 \\
\hline $\mathrm{b}$ & $\mathrm{TL}$ & $0.9 \% \mathrm{NaCl}$ & Opalescent & 8 & 200 & & 28 \\
\hline c & PL & $0.9 \% \mathrm{NaCl}$ & Opalescent & 8 & & & 56 \\
\hline $3 a$ & PL & $\begin{array}{c}\text { Phosphate } \\
\text { buffer }\end{array}$ & Clear & 28 & & 57 & 70 \\
\hline $\mathrm{b}$ & PL & $\begin{array}{c}\text { Patient's } \\
\text { serum }\end{array}$ & Clear & 102 & & & 80 \\
\hline
\end{tabular}

* All emulsions shown in this table were prepared by ultrasonication (see Methods). PL, phospholipid; NL, neutral lipid; Chol, cholesterol; TL, total lipid.

mentation with a commercial triglyceride emul$\operatorname{sion}^{3}$ was ineffective. None of the emulsions significantly altered the autohemolysis of normal blood.

\section{B) Lipid analysis and autohemolysis of centrifu- gally separated acanthocytes}

Differences in autohemolytic behavior and membrane composition of younger as compared with more mature or older cells, or both, were then investigated. In four experiments, red cells were separated into younger and "older" populations as previously described (1). Data establishing the efficiency of the separation in one of these experiments have been presented in the accompanying paper (1). In the other experiments cell shape distribution, mean corpuscular hemoglobin concentration (MCHC), and reticulocyte percentages indicated proportionally similar enrichment of the upper layer with younger cells. In two of these, the average cells could also be differentiated from the bottom layer on the basis of the same measurements; but in the remaining experiment, good separation of average and "older" cells was not achieved.

\footnotetext{
${ }^{3}$ Intravenous Lipomul, Upjohn Co., Kalamazoo, Mich.
}

The amount of lipid phosphorus and cholesterol per cell was greater in the top cells than in the average population, and less in the bottom layer (Table III). Although the average values for phospholipid distribution show relatively more lecithin in the top layer than in the average or bottom fractions, comparable reciprocal differences in sphingomyelin distribution were not convincing. In two experiments, autohemolysis of the separated cell populations was compared ( $\mathrm{Ta}-$ ble III). More cells from the bottom layer and fewer from the top lysed in relation to the mixed cell population.

\section{Discussion}

We have investigated the factors in normal serum responsible for inhibition of acanthocyte autohemolysis (1). To facilitate interpretation of the findings, we will review briefly a simplified ultracentrifugal classification of plasma lipoproteins and data concerning their lipid composition (9-11). In the fasting state the fractions of density less than 1.063 and density 1.063 to 1.21 ("low density lipoprotein" and "high density lipoprotein") comprise $90 \%$ of circulating lipoproteins. They contain the major proportion of plasma phospholipid (lecithin and sphingomyelin), 
TABLE III

Lipid analyses and autohemolytic behavior of centrifugally separated cells*

\begin{tabular}{|c|c|c|c|c|c|c|c|c|c|}
\hline & \multirow[b]{3}{*}{$\mathrm{MCHC} \dagger$} & \multirow{3}{*}{$\begin{array}{c}\text { Lipid } \\
\text { phos- } \\
\text { phorus† }\end{array}$} & \multirow{3}{*}{$\begin{array}{c}\text { Choles- } \\
\text { terolf }\end{array}$} & \multirow{2}{*}{\multicolumn{4}{|c|}{ Phospholipid distribution $\dagger$}} & \multicolumn{2}{|c|}{ Autohemolysis } \\
\hline & & & & & & & & \multirow{2}{*}{$\underset{4^{\circ} \mathrm{CD} \ddagger}{\mathrm{EDT}}$} & \multirow{2}{*}{$\begin{array}{l}\text { Washed } \\
\text { cells, } \\
22^{\circ} \mathrm{C} \ddagger\end{array}$} \\
\hline & & & & Lec & $\mathrm{Sp}$ & $\mathrm{PE}$ & PS & & \\
\hline & $\mathrm{g} / 100 \mathrm{ml}$ & \multicolumn{2}{|c|}{$m g \times 10^{-10} /$ cell } & \multicolumn{4}{|c|}{$\%$ tolal phosphorus recovered } & $\%$ & $\%$ \\
\hline Top & 29.3 & 0.149 & 1.60 & 24.7 & 29.7 & 22.0 & 17.2 & 9 & 5 \\
\hline Average & 34.0 & 0.112 & 1.27 & 22.5 & 36.0 & 19.5 & 15.1 & 14 & 15 \\
\hline Bottom & 37.0 & 0.103 & 1.16 & 21.6 & 32.4 & 21.4 & 16.0 & 22 & 32 \\
\hline
\end{tabular}

* MCHC, mean corpuscular hemoglobin concentration; Lec, lecithin; Sp, sphingomyelin; PE, phosphatidyl ethanolamine; PS, phosphatidyl serine.

$\dagger$ MCHC, lipid phosphorus, and cholesterol were not analyzed in one of the four experiments and phospholipid distribution in another; these values represent the average of three experiments.

$\ddagger$ Single experiment.

cholesterol, and triglyceride. The fraction of density greater than 1.21 contains high levels of nonesterified fatty acid, lysolecithin (12), and virtually no triglyceride or cholesterol.

In these experiments, serum from a patient with elevated triglycerides was less active in inhibiting autohemolysis than any of the normal sera tested. Therefore, no activity can be attributed to the small amount of triglyceride present in normal fasting serum (or in the isolated lipoprotein fraction of density less than 1.063). Moreover, since the fraction of density greater than 1.21 was detrimental, it contains either none of the active material or enough harmful substances (possibly free fatty acid or lysolecithin) to overcome the favorable effect of any inhibitor present.

On the other hand, the high and low density lipoproteins-rich in phospholipid and cholesterol but also containing specific proteins, tocopherols $(13,14)$, carotenoids $(15,16)$, neutral sugars, hexosamines, and sialic acid (8)-were consistently active inhibitors of in vitro acanthocyte lysis. Since the protein moieties of high and low density lipoprotein differ (15) and a commercial "beta lipoprotein" preparation containing virtually no lipid did not reduce autohemolysis, the protein portion of the molecule has no apparent antihemolytic potency in the systems used. A similar conclusion can be drawn regarding glucosamine and $N$-acetylneuraminic acid.

Conversely, the additional activity of serum with high cholesterol and phospholipid levels, and the beneficial effects of certain emulsions containing both phospholipid and cholesterol, sug- gest that some complex containing both these major lipid entities may contain the activity. Since in some experiments, inhibition was achieved although the final concentration of cholesterol and lipid phosphorus in the supplemented tube was equal to or lower than in the patient's serum alone (Table I), the physical-chemical nature of such a complex may be more critical than its absolute lipid content. Alternatively, it may contain other substances not found in acanthocytosis serum.

Could any single component of such a hypothetical "complex" be the active factor? Phospholipid seems unlikely, since clear emulsions of phospholipid alone were not effective. Cholesterol alone cannot be excluded, since emulsions of cholesterol in the absence of phospholipid were not attained. Vitamin A esters, beta carotenoids, and tocopherols are present in isolated lipoprotein (13-16) and if not degraded, would be isolated in the neutral lipid fraction of extracted and chromatographed plasma lipid. Since the patient's vitamin A level was normal (although he did have low levels of carotene), deficient lipoprotein-bound vitamin A would seem an unlikely cause for the increased lysis. The plasma tocopherol was not measured, and the role of the vitamin E compounds cannot, therefore, be assessed.

These investigations suggest that whatever the nature of the active material, it might protect the cell from abnormal permeability to hemoglobin a) by serving as a substrate for some critical intracellular metabolic reaction or $b$ ) by becoming a structural, functional (metabolic), or protective component of the cell membrane. 
The small amount of serum required, its beneficial effect without improved maintenance of intracellular ATP (1), and the size of the active substance (nondialyzable) all argue against hypothesis $a$ ).

A functional basis for the second possibility exists. Thus, an exchange of cholesterol (17, 18), phospholipid fatty acids (19), and phospholipid phosphorus (20) between normal human plasma and red cells in vivo and of phospholipid phosphorus between normal plasma and acanthocytes in vitro (21) has been demonstrated. Defects in such exchange processes (secondary to deficient plasma lipoprotein) could produce cell abnormalities. Indeed, the data presented here and in other papers $(1,6)$ suggest that the abnormal plasma environment in acanthocytosis does influence cell shape and autohemolytic behavior. Evidence that the abnormal plasma environment might also be responsible for the abnormal membrane lipid composition of acanthocytes is suggestive but less convincing. Although less phospholipid and cholesterol were found in the "older" cells than in the average population, a progression in the abnormal distribution of phospholipids was not conclusively demonstrated. Using a different separation technique, Phillips (7) was also unable to demonstrate significant differences in phospholipid distribution in lighter and heavier cells. ${ }^{4}$

4 Using centrifugal separation techniques, two investigations $(22,23)$ have reported a decrease in lipid content of normal red cells with in vivo aging. In one of these reports, however, evidence given does not clearly indicate separation of senescent from mature cells (23). In the other study (22), the data on this point are more convincing, and less phospholipid (but not cholesterol) is seemingly present in the older than in the "average" cells. However, the report does not state that the "average" cells were handled technically in the same manner as the "older" cells, and the data provided are not sufficient to determine the degree of enrichment of the bottom layer with older cells.

Brecher and Stohlman (24) have shown that the sedimentation of red cells in a centrifugal field is a function of their MCHC. The much larger range in $\mathrm{MCHC}$ of the acanthocytes studied here, as compared with normal cells (25), would, therefore, suggest that a more efficient separation was achieved. Although this seems likely, proof (i.e., $\mathrm{Fe}^{59}$ localization at the bottom of the centrifugal column at an appropriate time interval after labeling) was not obtained. Until this is done and until comparable separation can be achieved and proven with normal cells, the significance of the decreased cholesterol
These data may mean that the heavier populations were not sufficiently enriched with older cells to demonstrate existing differences in phospholipid composition, or that the abnormalities in membrane lipids are not so clearly a function of in vivo aging as the shape changes and autohemolysis.

It is crucial to document conclusively whether the deficient and abnormal plasma lipids and lipoproteins per se, or some substance complexed with them, is the cause of the red cell lipid abnormalities in acanthocytosis, since similar effects on the central nervous system could contribute significantly to the disabling neurological defects.

Finally, the autohemolysis may provide a most valuable tool for assessing the efficacy of potential therapeutic measures in acanthocytosis. The red cell mass is renewed every few months or less. Conceivably, measures that reduce or eliminate the abnormal autohemolysis may ultimately be beneficial to the more critical membranes of the central nervous system as well.

\section{Summary}

1. Small amounts of whole serum, separated low and high density lipoproteins, and certain emulsions of plasma lipids inhibit the autohemolysis of acanthocytes. This activity is not inhibited by dialysis or heating to $56^{\circ} \mathrm{C}$ for one-half hour.

2. A discrete substance responsible for this activity was not identified, but the data suggest that a complex containing phospholipid, cholesterol, or some lipid soluble trace component of normal serum high and low density lipoprotein, or all three, is responsible.

3. Like the shape abnormalities of acanthocytes, their susceptibility to autohemolysis is increased with in vivo cell aging.

4. The data suggest but do not prove a quantitative decrease in red cell phospholipid and cholesterol with in vivo aging, but meaningful differences in phospholipid composition between younger and "older" cells were not found.

5. Autohemolysis of acanthocytes may provide a valuable tool for assessing the efficacy of therapeutic measures in this disease.

and phospholipid content of the bottom cells in acanthocytosis as compared with the average or top layer cannot be assessed. 


\section{Acknowledgments}

The authors are grateful to Dr. John Jones for preparing some of the plasma lipids and lipoproteins and to Dr. Claude Reed for providing laboratory facilities and assistance for certain of the autohemolysis studies.

\section{References}

1. Simon, E. R., and P. Ways. Incubation hemolysis and red cell metabolism in acanthocytosis. J. clin. Invest. 1964, 43, 1311.

2. Ways, P., C. F. Reed, and D. J. Hanahan. Redcell and plasma lipids in acanthocytosis. J. clin. Invest. 1963, 42, 1248.

3. Havel, R. J., H. A. Eder, and J. H. Bragdon. The distribution and chemical composition of ultracentrifugally separated lipoproteins in human serum. J. clin. Invest. 1955, 34, 1345.

4. Salt, H. B., O. H. Wolff, J. K. Lloyd, A. S. Fosbrooke, A. H. Cameron, and D. V. Hubble. On having no beta-lipoprotein: a syndrome comprising A-beta-lipoproteinemia, acanthocytosis, and steatorrhœa. Lancet 1960, 2, 325.

5. Mabry, C. C., A. M. DiGeorge, and V. H. Auerbach. Studies concerning the defect in a patient with acanthrocytosis (abstract). Clin. Res. 1960, 8, 371.

6. Rey, J. L'Absence Congénitale de Bêta-Lipoprotéines. Thèse. Paris, R. Foulon, 1961.

7. Phillips, G. B. Quantitative chromatographic analysis of plasma and red cell lipids in patients with acanthocytosis. J. Lab. clin. Med. 1962, 59, 357.

8. Marshall, W. E., and F. A. Kummerow. The carbohydrate constituents of human serum $\beta$-lipoprotein : galactose, mannose, glucosamine and sialic acid. Arch. Biochem. 1962, 98, 271.

9. Bragdon, J. H., R. J. Havel, and E. Boyle. Human serum lipoproteins. I. Chemical composition of four fractions. J. Lab. clin. Med. 1956, 48, 36.

10. Lindgren, F. T., and A. V. Nichols. Structure and function of human serum lipoproteins in The Plasma Proteins, F. W. Putnam, Ed. New York, Academic Press, 1960, vol. 2, p. 1.

11. Jones, J., and P. Ways. Unpublished data.
12. Phillips, G. B. Lipid composition of human serum lipoprotein fraction with density greater than 1.210. Proc. Soc. exp. Biol. (N. Y.) 1959, 100, 19.

13. Borgstrom, B. Investigation of lipid separation methods. Separation of cholesterol esters, glycerides, and free fatty acids. Acta physiol. scand. 1952, 25, 111.

14. Vasington, F. D., S. M. Reichard, and A. Nason. Biochemistry of vitamin $\mathrm{E}$ in Vitamins and Hormones. Chicago, Academic Press, 1960, vol. 18, p. 50.

15. Gurd, F. Some naturally occurring lipoproteins in Lipide Chemistry, D. J. Hanahan, Ed. New York, John Wiley and Sons, 1960, p. 260.

16. Pitt, G. A. J., and R. A. Morton. Fat-soluble vitamins. Ann. Rev. Biochem. 1962, 31, 491.

17. Gould, R. G., G. V. LeRoy, G. T. Okita, J. J. Kabara, P. Keegan, and D. M. Bergenstal. The use of C-14 labeled acetate to study cholesterol metabolism in man. J. Lab. clin. Med. 1955, 46, 372.

18. London, I. M., and H. Schwarz. Erythrocyte metabolism. The metabolic behavior of the cholesterol of human erythrocytes. J. clin. Invest. 1953, 32, 1248.

19. Farquhar, J. W., and E. H. Ahrens, Jr. Effects of dietary fats on human erythrocyte fatty acid patterns. J. clin. Invest. 1963, 42, 675.

20. Reed, C. F. Studies of in vivo and in vitro exchange of erythrocyte and plasma phospholipids (abstract). J. clin. Invest. 1959, 38, 1032.

21. Ways, P., and C. F. Reed. Unpublished data.

22. Prankerd, T. A. J. The ageing of red cells. J. Physiol. (Lond.) 1958, 143, 325.

23. Westermann, M. P., L. E. Pierce, and W. E. Jensen. Erythrocyte lipids: a comparison of normal young and normal old populations. J. Lab. clin. Med. 1963, 62, 394.

24. Brecher, G., and F. Stohlman, Jr. Reticulocyte size and erythropoietic stimulation. Proc. Soc. exp. Biol. (N. Y.) 1961, 107, 887.

25. Bernstein, R. E. Alterations in metabolic energetics and cation transport during aging of red cells. J. clin. Invest. 1959, 38, 1572.

\section{SPECIAL NOTICE TO SUBSCRIBERS}

Post Offices will no longer forward the Journal when you move.

Please notify The Journal of Clinical Investigation, Business Office, 10 Stoughton Street, Boston, Mass. 02118, at once when you have a change of address, and do not omit the Zip Code number. 